university through royalty arrangements, the thinking of university administrators has moved on. It is now widely accepted that, aside from the occasional jackpot of the sort enjoyed by Columbia University in New York (whose 'Axel patents' for gene insertion have earned it more than $\$ 300$ million), technology-transfer offices are unlikely to generate large income streams. Instead, their principal role is to develop universities' ties with business in ways that should benefit students, staff and the surrounding community.

At last month's annual meeting of the Association of University Technology Managers, which drew some 2,000 technology-transfer officials from around the world to Orlando, Florida, the association's leadership declared: "It's not about the money." The meeting's busiest sessions were about the money, of course. But the point still stands: the remit of technology managers has grown far wider than just the collection of royalty payments.

For their part, technology managers find some researchers to be rather naive in their expectations regarding interactions with industry. Academics are sometimes slow to acknowledge potential pitfalls, such as pending ownership disputes over intellectual property. They can be too ready to sign over their future ideas in so-called 'honeymoon' deals, where a tightly controlled arrangement for the technology in hand would make more sense. More crucially, as technology managers see it, researchers take too sanguine a view of their would-be industrial partners, or their new-found venture-capital backers, on the other side of the table.

Like the technology managers, academic researchers are still on a

learning curve. But they know much more these days about business deals, and are aware of the broader role that scientific research plays in economic development.

The interests of the technology-transfer offices are broadening out. For example, Cambridge Enterprise has some 20 staff and expertise that reaches beyond patenting and licensing agreements to the distribution of seed capital to promising young firms (see page 867). Research universities all over the world are looking for the latter: seed money from private sources is hard to find, and various mechanisms are under investigation to keep it flowing (see Nature 440, 738-739; 2006). Even in technology hotspots

"Ideally, technology-
transfer offices should
be atrusted resource for
university scientists."
such as Silicon Valley, a slowing flow of venture capital for earlystage company development makes it a topic for universities to address themselves.

Ideally, technology-transfer offices should be a trusted resource for university scientists, working to protect their interests and establishing the right kind of relationships with commercial partners. Some academics can do that for themselves, but most need professional assistance.

Politicians and industrial managers increasingly view the research university as an essential source of the innovative ideas that drive modern economies. University technology managers and academics should work together to make the most of their strong position.

\section{Neglected neighbour}

\section{Venus Express will go some way towards correcting a strange disparity.}

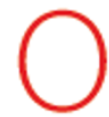

ur two neighbouring planets form a stark contrast: one dedicated to love, a diamond in the evening, a pearl in the morning; the other dimmer, ruddier and tainted with bellicosity. You might think that each would get its fair share of our world's attention, but recently this has not been so.

The European Space Agency's Venus Express was due to enter orbit around Venus on 11 April, becoming its first Earthly visitor since Magellan, a NASA orbiter launched in 1989. In that interval, 15 separate spacecraft have been sent to probe the mysteries of Mars.

Yet Venus has plenty of mysteries of its own. Its high-level winds tear around at a speed no one can understand, and its surface bears the scars of an extraordinary cataclysm that overwrote most of its previous history less than a billion years ago. Scientists have developed little understanding of how this planet, so similar in size to Earth and yet so different from it, actually works.

In terms of maintaining Earthly interest, though, veiled Venus may have been mysterious for too long. The fact that the surface of Mars can be seen from Earth made it an appealing locale for fiction and fantasy. The astronomer Percival Lowell's vision of Mars as a desert planet, once Earth-like but now dying, gripped the twentiethcentury imagination. As a distant desert, perhaps replete with strange and ancient inhabitants, Mars seemed to offer something akin to a new frontier. So while Venus stayed a planet, Mars became a world.

Closer examination of Mars has shown that aspects of its geological history can be made to fit into this story, offering evidence compatible with a wetter and more habitable past that could also be taken as an invitation to an inhabited future. A mixture of science and story-telling thus made Mars the planet most studied for traces of life, and most speculated on as a destination for human explorers.

Venus fans point out that it, too, has possibilities along these lines. Like Mars, it must have enjoyed a less inclement youth, with oceans in which early life may have bathed. Unfortunately, Venus has erased almost all obvious signs of its earlier state. Even so, there are no rock-solid grounds for excluding the possibility that remnants of a venusian biosphere persist in its clouds to this day.

Nor is Venus an impossible

"Like Mars, Venus must
have enjoyed a less
inclement youth, with
oceans in which early life
may have bathed."
candidate for human exploration. Its surface presents conditions more akin to the inside of an industrial chemical plant than to those encountered on a geological field trip. But journeys through its cloudscapes in dirigibles might still conceivably be less problematic than establishing a base on the cold, toxic, dust-devilled surface of Mars.

Without the narrative background into which our hopes for Mars are embedded, ideas of visiting Venus are unlikely to gain much traction. It is likely that Venus Express will yield gigabytes of fascinating data, greatly enriching knowledge of our nearest planetary neighbour. But if the mission is to usher in an age of Venus exploration, it will need to send back a compelling story too. 